\title{
Paracoccus haeundaensis sp. nov., a Gram-negative, halophilic, astaxanthin-producing bacterium
}

\author{
Jae Hyung Lee, Yun Sook Kim, Tae-Jin Choi, Won Jae Lee \\ and Young Tae Kim \\ Department of Microbiology, Pukyong National University, Busan 608-737, Korea
}

Correspondence

Young Tae Kim

ytkim@pknu.ac.kr

\begin{abstract}
An aerobic, non-motile, Gram-negative, orange-pigmented, rod-shaped, astaxanthin-producing marine bacterium was isolated from the Haeundae Coast, Korea. This strain, $B C 74171^{\top}$, produced carotenoids, mainly astaxanthin. All the type strains of the genus Paracoccus were compared with strain $\mathrm{BC} 74171^{\top}$ using $16 \mathrm{~S}$ rRNA gene sequence analysis, fatty acid patterns and physiological reaction profiles. Based on the results of these analyses, it is proposed that strain $\mathrm{BC} 74171^{\top}$ represents a novel species, Paracoccus haeundaensis sp. nov. The type strain is $B C 74171^{\top}\left(=\mathrm{KCCM} 10460^{\top}=\mathrm{LMG} \mathrm{P}-21903^{\top}\right)$.
\end{abstract}

Astaxanthin ( $3,3^{\prime}$-dihydroxy- $\beta, \beta$-carotene- $4,4^{\prime}$-dione $)$ is a carotenoid that is widely distributed in nature and is present in marine animal tissues, including those of red sea bream, salmon and lobster (Fujita et al., 1983; Johnson \& An, 1991; Nelis \& De Leenheer, 1991). Organisms that produce astaxanthin include the basidiomycetous yeast Phaffia rhodozyma (Miller et al., 1976), the green alga Haematococcus pluvialis (Bubrick, 1991), and the Gramnegative bacteria 'Agrobacterium aurantiacum' (Yokoyama et al., 1994), Paracoccus marcusii (Harker et al., 1998), Paracoccus carotinifaciens (Tsubokura et al., 1999) and Paracococcus sp. strain MBIC 01143 (Misawa et al., 1995).

The genus Paracoccus consists of Gram-negative, oxidaseand catalase-positive bacteria that show substantial metabolic versatility. At present, the genus Paracoccus includes 17 recognized species. Phylogenetically, the genus belongs to the $\alpha-3$ subclass of the Proteobacteria. In this study, results of a taxonomic study and a phylogenetic analysis based on $16 \mathrm{~S}$ rRNA gene sequence comparisons are described. Data show that a newly isolated marine strain, $\mathrm{BC} 74171^{\mathrm{T}}$, should be classified as a representative of a novel species within the genus Paracoccus. The name Paracoccus haeundaensis sp. nov. is proposed; the type strain is $\mathrm{BC} 74171^{\mathrm{T}}$ ( $=\mathrm{KCCM}$ $\left.10460^{\mathrm{T}}=\mathrm{LMG} \quad \mathrm{P}-21903^{\mathrm{T}}\right)$ and its characteristics are described.

Published online ahead of print on 19 March 2004 as DOI 10.1099/ ijs.0.63146-0.

The GenBank/EMBL/DDBJ accession number for the 16S rRNA gene sequence of strain $B C 74171^{\top}$ is $A Y 189743$.

A transmission electron micrograph of strain $\mathrm{BC} 74171^{\top}$ and a table showing selected characteristics of Paracoccus haeundaensis sp. nov. and related Paracoccus species are available as supplementary material in IJSEM Online.
An orange-pigmented, astaxanthin-producing bacterial strain, BC74171 ${ }^{\mathrm{T}}$, was isolated from sea water collected on the Haeundae Coast, Korea. This strain was isolated on nutrient agar medium (Difco) and maintained on PPES-II medium $(0 \cdot 2 \%$ polypeptone, $0 \cdot 1 \%$ Bacto-yeast extract, $0 \cdot 1 \%$ Bacto-soytone, $0 \cdot 1 \%$ Bacto-tryptone, 10 p.p.m. ferric citrate and $3 \% \mathrm{NaCl}$ ) by serial inoculation. Strain BC74171 ${ }^{\mathrm{T}}$ was Gram-negative and rod-shaped. The cells ranged from 0.3 to $0.7 \mu \mathrm{m}$ in diameter and 0.8 to $2.5 \mu \mathrm{m}$ in length. Cells were non-motile and non-spore-forming. Colonies on agar were smooth, flat and bright orange in colour.

Cultured cells were suspended in $0 \cdot 1 \mathrm{M}$ phosphate buffer $(\mathrm{pH} 7 \cdot 2)$. Cells were fixed with $2 \%$ glutaraldehyde, washed with $0.05 \mathrm{M}$ cacodylate buffer and post-fixed with $1 \%$ osmium tetroxide. Fixed cells were dehydrated in ethanol and the ethanol was replaced with propylene oxide before embedding in Epon resin and sectioning with an ultramicrotome. Sections were examined with a JEM 1200EX-II transmission electron microscope (Fig. 1; see also the transmission electron micrograph available as supplementary material in IJSEM Online).

Strain $\mathrm{BC} 74171^{\mathrm{T}}$ was cultivated for 2 days at $25^{\circ} \mathrm{C}$ on modified trypticase soy agar (TSA, $2 \% \mathrm{NaCl}$ added) adjusted to $\mathrm{pH} 8 \cdot 0$. Harvesting, saponification, methylation and extraction of the fatty acid methyl esters were performed according to Sasser (1990). Fatty acid methyl esters were identified by GC-MS, as described previously (Lipski \& Altendorf, 1997).

The fatty acid profile $\left(\mathrm{C}_{18: 1}, 84 \cdot 32 \% ; \mathrm{C}_{18: 0}, 7 \cdot 79 \% ; \mathrm{C}_{10: 0}\right.$ 3-OH, $2.06 \%$; $\mathrm{C}_{12: 1}$ cis5, $2.0 \%$; $\mathrm{C}_{14: 0} 3-\mathrm{OH}, 1.47 \%$; $\mathrm{C}_{17: 0}$, $0.80 \% ; \mathrm{C}_{16: 0}, 0.78 \%$; and unknown peaks, $0.78 \%$ ) is characteristic of the $\alpha$-Proteobacteria. The major cellular non-hydroxyl fatty acid is unsaturated $\mathrm{C}_{18: 1}$. The major 


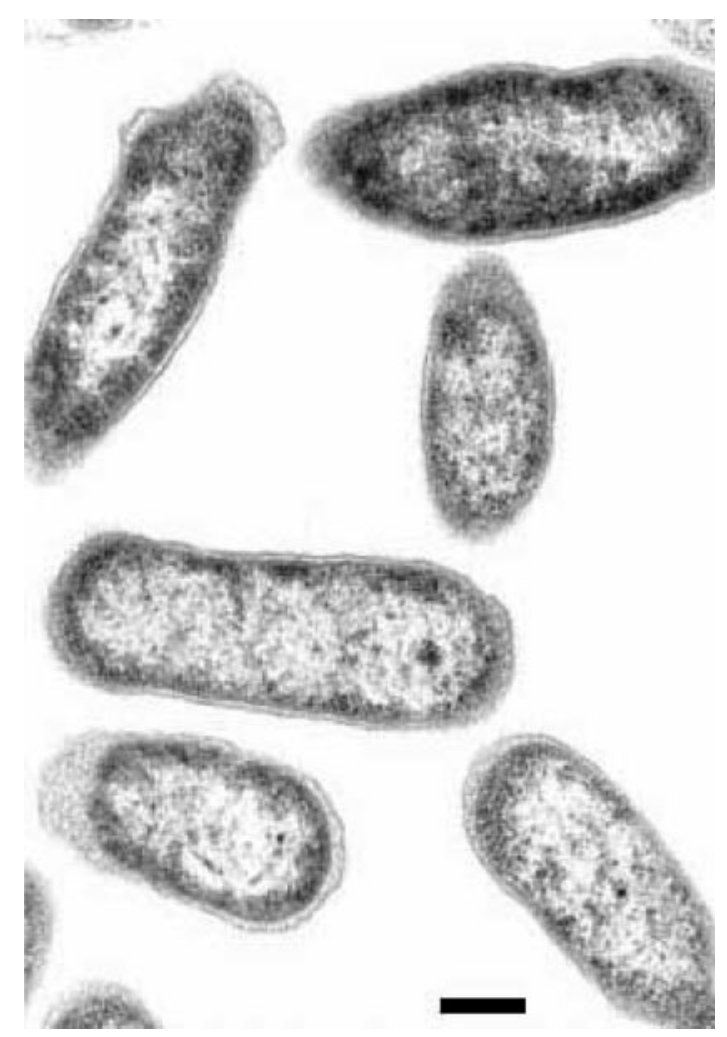

Fig. 1. Transmission electron micrograph of cells of Paracoccus haeundaensis strain $\mathrm{BC} 74171^{\top}$ during the exponential stage of growth. Bar, $200 \mathrm{~nm}$.

hydroxyl fatty acid is $\mathrm{C}_{10: 0} 3-\mathrm{OH}$. The bright orange colouration of the bacterium was shown to result from biosynthesis of carotenoids within the cells. Pigments were extracted with acetone, analysed by HPLC and monitored by measuring $A_{470}$. One of the major pigments that accumulated in the cell wall was astaxanthin, which was identified by spectroscopic analysis using a standard solution of authentic astaxanthin.

Strain $\mathrm{BC} 74171^{\mathrm{T}}$, P. marcusii DSM $11574^{\mathrm{T}}$ and Paracoccus sp. strain MBIC 01143 were grown on PPES-II medium and subjected to physiological characterization. The temperature range for growth was determined by incubating cells for 10 days on plates of nutrient agar at the following temperatures: $4,10,20,25,28,30,37,40$ and $50^{\circ} \mathrm{C}$. The $\mathrm{pH}$ range for growth was determined by incubating cells in PPES-II broth medium at $25{ }^{\circ} \mathrm{C}$ for 10 days at the following pH: $3 \cdot 0,4 \cdot 0,5 \cdot 0,6 \cdot 0,6 \cdot 5,7 \cdot 0,8 \cdot 0,9 \cdot 0,10 \cdot 0,10 \cdot 5$ and $11 \cdot 0 . \mathrm{NaCl}$ tolerance was measured in trypticase soy broth (TSB) at concentrations of $0-10 \%(\mathrm{w} / \mathrm{v})$. Motility was determined with an optical microscope using the hanging-drop technique (Skerman, 1967). To investigate its morphological and physiological characteristics, strain BC74171 ${ }^{\mathrm{T}}$ was, in most cases, cultivated on TSA or in broth with $2 \% \mathrm{NaCl}$ added, at $25^{\circ} \mathrm{C}$. Acid production from some carbohydrates was detected using the method of Hugh \&
Leifson (1953). Growth was monitored by measuring turbidity after 10 days incubation at $25^{\circ} \mathrm{C}$ with shaking. Starch hydrolysis was determined as described by Cowan \& Steel (1965). Denitrification was determined by growth and gas formation in a stab culture of nutrient agar containing $0 \cdot 1 \%(\mathrm{w} / \mathrm{v})$ agar. Catalase activity was determined by the presence of bubbles in a $3 \% \mathrm{H}_{2} \mathrm{O}_{2}$ solution. Oxidase activity was determined by oxidation of $1 \%$ $p$-aminodimethylaniline oxalate. Urease production was determined as described by Lanyi (1987).

Strain $\mathrm{BC} 74171^{\mathrm{T}}$ grew at $20-37^{\circ} \mathrm{C}$, but not at $4,10,40$ or $50{ }^{\circ} \mathrm{C}$; the optimal growth temperature was $25-30^{\circ} \mathrm{C}$. Slow growth was observed in TSB in the absence of $\mathrm{NaCl}$. The optimum $\mathrm{NaCl}$ concentration for growth was $1-6 \%$. When the $\mathrm{NaCl}$ concentration in the medium was increased to $7 \%$, growth was slow. No growth occurred in the presence of more than $8 \%(\mathrm{w} / \mathrm{v}) \mathrm{NaCl}$. Growth was very slow or inhibited below $\mathrm{pH} 6 \cdot 0$ and above $\mathrm{pH} 10 \cdot 5$. Glucose was not fermented. Metabolism was aerobic.

Extraction of genomic DNA and amplification of the 16S rRNA gene were carried out as described by Rainey et al. (1992). The PCR product was ligated into a PGEM-T vector (Promega), sequenced using a Termination Sequencing Ready Reaction kit (Perkin Elmer) and electrophoresed using an ABI 377 genetic analyser (Perkin Elmer). The resulting sequence data were analysed with programs BLASTN and BLASTX of GenBank. Sequences were aligned using the program CLUSTAL W. Gaps at the $5^{\prime}$ and $3^{\prime}$ ends of the alignment were omitted from further analyses. To indicate confidence in the branching order, bootstrap analysis (1000 replications) was completed for both the distance and parsimony methods. A phylogenetic dendrogram was obtained using the program TREEVIEW (Fig. 2). The full-length 16S rRNA gene from strain $\mathrm{BC} 74171^{\mathrm{T}}$ was sequenced. The sequence of strain $\mathrm{BC} 74171^{\mathrm{T}}$ shared the greatest similarity with the sequences of $P$. marcusii and P. carotinifaciens ( $99 \cdot 8$ and $99 \cdot 6 \%$ similarity, respectively).

The $\mathrm{G}+\mathrm{C}$ content of the genomic DNA was determined by the method of Tamaoka \& Komagata (1984). The DNA was hydrolysed and the resultant nucleotides were analysed by reversed-phase HPLC. DNA-DNA hybridization was performed fluorometrically by the method of Ezaki et al. (1989) using photobiotin-labelled DNA probes and microdilution wells. Hybridization was performed with five replications for each sample. Of the values obtained, the highest and lowest values in each sample were excluded; the DNA-DNA relatedness values are expressed as the mean of the remaining three values.

The $\mathrm{G}+\mathrm{C}$ content of the DNA of strain $\mathrm{BC} 74171^{\mathrm{T}}$ was $66 \cdot 9 \mathrm{~mol} \%$ (by HPLC analysis). DNA-DNA hybridization was performed to determine the genomic relatedness between strain $\mathrm{BC} 74171^{\mathrm{T}}$ and some Paracoccus species. Strain BC74171 ${ }^{\mathrm{T}}$ exhibited mean levels of DNA-DNA relatedness to the type strains of Paracoccus denitrificans, Paracoccus thiocyanatus, Paracoccus versutus and P. marcusii, 


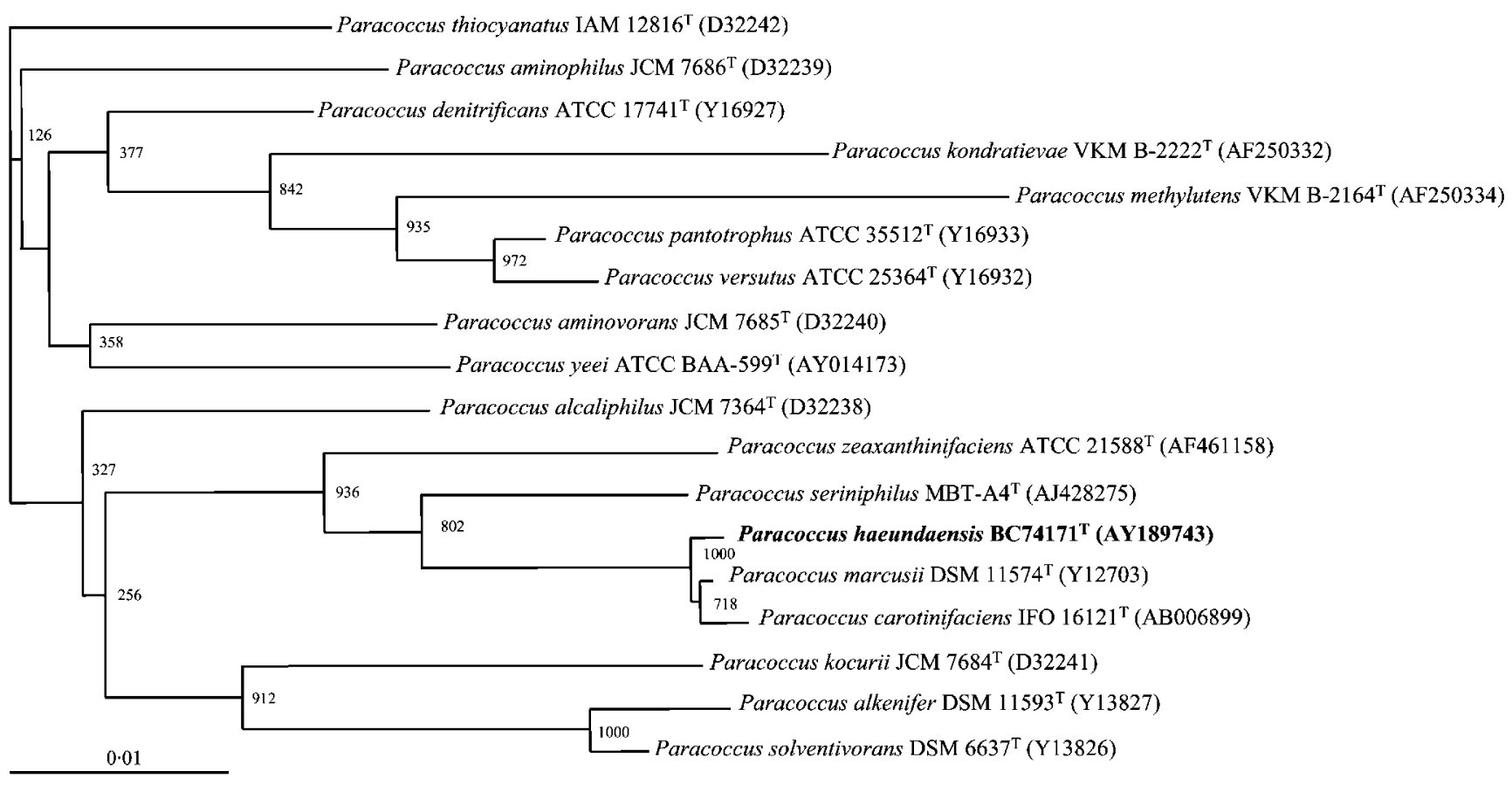

Fig. 2. Phylogenetic tree based on $16 \mathrm{~S}$ rRNA gene sequence analysis of members of the genus Paracoccus. Bar, Jukes \& Cantor (1969) distance and maximum-parsimony distance (1 nt substitution per $100 \mathrm{nt})$. Numbers on branch nodes are bootstrap values (1000 replications).

and Paracoccus sp. strain MBIC 01143 of 8, 7, 6, 47 and $11 \%$, respectively, when each of their DNAs was used separately as a labelled probe.

The genus Paracoccus comprises a group of aerobic, Gramnegative bacteria that are catalase- and oxidase-positive and reduce nitrate. Seventeen recognized species of this genus have been identified. Details of physiological characteristics of $P$. haeundaensis and several type strains belonging to the genus Paracoccus are available as supplementary material in IJSEM Online.

The 16S rRNA gene sequence of $P$. haeundaensis shared high similarity with the sequences of $P$. marcusii and $P$. carotinifaciens and all three are astaxanthin-producing bacteria. The type strain of $P$. carotinifaciens is deposited only in IFO ( $=$ IFO $16121^{\mathrm{T}}$ ) as a patented strain and is not publicly available. In a case like this, $P$. carotinifaciens contravenes the revised Rule 27(3) and Rule 30 of the Bacteriological Code (Euzéby \& Tindall, 2004). Therefore, direct biochemical comparison and DNA-DNA hybridization studies between $P$. haeundaensis and P. carotinifaciens could not be performed. The biochemical characteristics of $P$. carotinifaciens were taken from a published report (Tsubokura et al., 1999). P. marcusii occurs as a coccus or short rod and forms short chains, whereas both $P$. haeundaensis and $P$. carotinifaciens occur as rods, but do not form chains. $P$. carotinifaciens has flagella, whereas $P$. haeundaensis does not. Moreover, the species have different phenotypic characteristics. P. haeundaensis does not utilize mannitol, maltose or mannose, whereas both $P$. marcusii and $P$. carotinifaciens utilize these compounds. In addition, $P$. haeundaensis hydrolyses starch, whereas neither $P$. marcusii nor $P$. carotinifaciens does.

\section{Description of Paracoccus haeundaensis sp. nov.}

Paracoccus haeundaensis (hae.un'dae.n.sis. N.L. adj. haeundaensis referring to Haeundae beach in Busan, Korea, where the type strain was isolated).

Gram-negative, non-motile, rod-shaped and non-sporeforming. Cells are $0 \cdot 3-0 \cdot 7 \mu \mathrm{m}$ in diameter and $0 \cdot 8-2 \cdot 5 \mu \mathrm{m}$ in length. Colonies are orange to red in colour. Optimal growth temperature is $25^{\circ} \mathrm{C}$; no growth occurs below $10^{\circ} \mathrm{C}$ or above $40^{\circ} \mathrm{C}$. The optimum $\mathrm{NaCl}$ concentration for growth is $1-6 \%(\mathrm{w} / \mathrm{v})$. No growth occurs in the presence of more than $8 \%(\mathrm{w} / \mathrm{v}) \mathrm{NaCl}$. Optimal $\mathrm{pH}$ for growth is 8 . Capable of producing astaxanthin. The major cellular nonhydroxyl fatty acid is unsaturated $\mathrm{C}_{18: 1}$. The major hydroxyl fatty acid is $\mathrm{C}_{10: 0} 3-\mathrm{OH}$. The following carbon and energy sources can be used for growth: D-arabinose and galactose. No growth occurs on D-glucose, lactose, maltose, sucrose, trehalose, D-mannitol, D-sorbitol, inositol, D-raffinose, D-fructose, D-mannose, dimethylformamide, L-glutamic acid, acetone, L-leucine, L-asparagine, L-rhamnose, salicin, D-cellobiose, adonitol, dulcitol, D-xylose or glycerol. L-Ornithine and L-lysine decarboxylases, and arginine dihydrolase are not detected. Citrate utilization test is 
positive. Starch is hydrolysed. No indole is produced from tryptophan. Cytochrome oxidase and catalase reactions are positive. Urease-negative. Nitrate is reduced. Denitrification does not occur. Glucose is not fermented. Metabolism is aerobic. DNA G $+\mathrm{C}$ content is $66.9 \mathrm{~mol} \%$.

The type strain is $\mathrm{BC} 74171^{\mathrm{T}}\left(=\mathrm{KCCM} 10460^{\mathrm{T}}=\mathrm{LMG}\right.$ P-21903 $3^{\mathrm{T}}$.

\section{Acknowledgements}

We would like to thank Professor J. Hirschberg (The Hebrew University of Jerusalem, Israel) for providing us with the type strain of Paracoccus marcusii. Also, we thank Dr N. Misawa (Marine Biotechnology Institute, Japan) for allowing us to use Paracoccus sp. strain MBIC 01143. This work was supported by the Special Research Fund (2000-3) of Algenetech through Pukyong National University, Korea.

\section{References}

Bubrick, P. (1991). Production of astaxanthin from Haematococcus. Bioresour Technol 38, 237-239.

Cowan, S. T. \& Steel, K. J. (1965). Manual for the Identification of Medical Bacteria. London: Cambridge University Press.

Euzéby, J. P. \& Tindall, J. (2004). Status of strains that contravene Rules 27(3) and 30 of the Bacteriological Code. Request for an Opinion. Int J Syst Evol Microbiol 54, 293-301.

Ezaki, T., Hashimoto, Y. \& Yabuuchi, E. (1989). Fluorometric deoxyribonucleic acid-deoxyribonucleic acid hybridization in microdilution wells as an alternative to membrane filter hybridization in which radioisotopes are used to determine genetic relatedness among bacterial strains. Int J Syst Bacteriol 39, 224-229.

Fujita, T., Satake, M., Watanabe, T., Kitajima, C., Miki, W., Yamaguchi, K. \& Konosu, S. (1983). Pigmentation of cultured red sea bream with astaxanthin diester purified from krill oil. Bull Jpn Soc Sci Fish 49, 1855-1865.

Harker, M., Hirschberg, J. \& Oren, A. (1998). Paracoccus marcusii sp. nov., an orange Gram-negative coccus. Int J Syst Bacteriol 48, $543-548$.
Hugh, R. \& Leifson, E. (1953). The taxonomic significance of fermentative versus oxidative metabolism of carbohydrates by various gram negative bacteria. J Bacteriol 66, 24-26.

Johnson, E. A. \& An, G.-H. (1991). Astaxanthin from microbial sources. Crit Rev Biotechnol 11, 297-326.

Jukes, T. H. \& Cantor, C. R. (1969). Evolution of protein molecules. In Mammalian Protein Metabolism, vol. 3, pp. 21-132. Edited by H. N. Munro. New York: Academic Press.

Lanyi, B. (1987). Classical and rapid identification methods for medically important bacteria. Methods Microbiol 19, 1-67.

Lipski, A. \& Altendorf, K. (1997). Identification of heterotrophic bacteria isolated from ammonia-supplied experimental biofilters. Syst Appl Microbiol 20, 448-457.

Miller, M. W., Yoneyama, M. \& Soneda, M. (1976). Phaffia, a new yeast genus in the Deuteromycotina (Blastomycetes). Int J Syst Bacteriol 26, 286-291.

Misawa, N., Satomi, Y., Kondo, K., Yokoyama, A., Kajiwara, S., Saito, T., Ohtani, T. \& Miki, W. (1995). Structure and functional analysis of a marine bacterial carotenoid biosynthesis gene cluster and astaxanthin biosynthetic pathway proposed at the gene level. $J$ Bacteriol 177, 6575-6584.

Nelis, H. J. \& De Leenheer, A. P. (1991). Microbial sources of carotenoid pigments used in foods and feeds. J Appl Bacteriol 70, 181-191.

Rainey, F. A., Dorsch, M., Morgan, H. W. \& Stackebrandt, E. (1992). 16S rDNA analysis of Spirochaeta thermophila: its phylogenetic position and implications for the systematics of the order Spirochaetales. Syst Appl Microbiol 15, 197-202.

Sasser, M. (1990). Identification of bacteria through fatty acid analysis. In Methods in Phytobacteriology, pp. 199-204. Edited by Z. Klement, K. Rudolph \& D. C. Sands. Budapest: Akademiai Kiado.

Skerman, V. B. D. (1967). A Guide to the Identification of the Genera of Bacteria, 2nd edn. Baltimore: Williams \& Wilkins.

Tamaoka, J. \& Komagata, K. (1984). Determination of DNA base composition by reversed-phase high-performance liquid chromatography. FEMS Microbiol Lett 25, 125-128.

Tsubokura, A., Yoneda, H. \& Mizuta, H. (1999). Paracoccus carotinifaciens sp. nov., a new aerobic Gram-negative astaxanthinproducing bacterium. Int J Syst Bacteriol 49, 277-282.

Yokoyama, A., Izumida, H. \& Miki, W. (1994). Production of astaxanthin and 4-ketozeaxanthin by the marine bacterium, Agrobacterium aurantiacum. Biosci Biotechnol Biochem 58, 1842-1844. 